\title{
Social and Environmental Management in the Municipalities of Minas Gerais, Brazil
}

\author{
José Roberto Pereira1, João Batista Rezende², Ana Alice Vilas Boas ${ }^{1}$ \\ ${ }^{1}$ Universidade Federal de Lavras, Lavras, MG, Brazil \\ ${ }^{2}$ Fundação João Pinheiro, Belo Horizonte, MG, Brazil \\ Email: jrobertopereira2013@gmail.com, joaobatistarezende@yahoo.com.br, ana.alice2013@yahoo.com.br
}

Received 4 January 2015; accepted 24 January 2015; published 27 January 2015

Copyright (C) 2015 by authors and Scientific Research Publishing Inc.

This work is licensed under the Creative Commons Attribution International License (CC BY).

http://creativecommons.org/licenses/by/4.0/

(c) (i) Open Access

\begin{abstract}
The objective of this study is to analyze the ability of the public management of environmental problems faced by the municipalities in the state of Minas Gerais, Brazil. The theoretical elements that underlie this article are related to environmental management and municipal public administration. We used the results of the natural vulnerability and the social potential of the indicator of municipal environmental management, as well as data on sanitation and waste disposal. The weaknesses of public administration are located in the counties of low population group. These municipalities do not have suitable structure, formal organization and power of decisiveness in dealing with environmental problems.
\end{abstract}

\section{Keywords}

\section{Municipalities, Public Administration, Environment, Sustainability}

\section{Introduction}

The discussion of environmental impacts of production processes is a worldwide phenomenon that began in the 1970s in central countries, which triggered a process that led to pressures on regulatory agencies, industries and government. Until the 1970, the industries of central countries were limited to meet environmental protection standards and analysis of accident risks imposed by government agencies, and following a reactive strategy and then the cleaning up process. From the 1980s, a change in how companies in these countries saw the environmental issues associated with its production process came to a head.

Environmental responsibility has become a necessity for survival and a requirement for ethical behavior and environmental organization. Such a change may be associated with three main factors: increase supply of products, processes and pollution control techniques; expansion of the environmental movements and diffusion of 
environmental issues for all sectors of society, consumers' awareness to boycott certain products of polluting firms or else consume, preferably, the environmentally friendly products.

This position of the company made the industries, especially the most harmful to the environment, take measures to ensure a less degrading environmental performance. In addition, public bodies of the environment began to play an important role as regulators of the shares of companies and promoters of a new environmental attitude. This paper focus in the state and Federal governments; however, they begin to share the concerns of municipal government.

Some municipalities in the state of Minas Gerais, especially those with larger populations and better economic and financial committees already have active environmental policy, as well as the support of institutions. On the other hand, a great number of municipalities with low overall population density, especially rural areas and the kind, have not become fully attentive to the environmental issues that they either may be facing or will face.

The population in general is not made aware of environmental problems and, therefore, is not organized to demand effective action of public agencies and private sector to prevent such problems. In small towns, agricultural activities have always been historically very important for the economy whilst the environment was relegated to a minor role. Consequently, it is fair to put forward the following questions: What are the main environmental problems of the mining municipalities related to public administration? How are the problems identified dealt with? Bearing this in mind, the objective of this study is to analyze the capacity of public administration in relation to environmental problems of the 853 municipalities in Minas Gerais. To that matter, we used the results the ecological zoning of the state of Minas Gerais (EEZ-MG), especially the charters of environmental vulnerability and social potential indicator of municipal environmental management. We also used the database of the Index Mining Social Responsibility [1] in relation to sanitation and the waste disposal for the local administration.

This paper is structured into five parts, as from this introduction. In the second part, we will present the theoretical elements concerns concerning environmental management and public local administration in Brazil, showing the importance of addressing environmental management and public administration. In the third section, we will present the methodological aspects of the natural vulnerability, potential social and mining index of social responsibility so that they can understand the results presented in the following section. The fourth section will present the results of natural vulnerability, the potential social indicator of local environmental management, as well as the results of IMRS focused on sanitation and waste treatment of the districts in population strata. In the fifth and final section, we will address the considerations regarding the scope of the study and exploratory scenarios that public administration must look into as far as environmental problems of cities are concerned.

\section{Environmental and Public Local Management in Brazil}

Environment is not just the sum scarce natural resources, but in fact, constitutes a common good and thus acquires a social status [2]. However, these authors argue that the private use of the environment may cause conflicts of interest, as well as generate public losses. Potential conflicts can be caused by lack of respect for individual property boundaries and political jurisdiction [3]. In this sense, the extension of a given environmental impact can achieve multiple social actors in conflict. This has happened more frequently and intensively in modern capitalist society. [4] explains how economic growth occurs, degrading the environment certainly effects their growth, and how it undermines one of the factors of production - natural capital. Nature, Earth and space should make the development process as elements of sustainability and conservation of ecosystems. The degradation or destruction of an ecosystem affects the quality of life of society because it reduces the flow of goods and services that the nature can offer humanity. What is more, [5] considered that this logic of economic growth finds its limits in that it fails to ensure the welfare of the future generations, depleting natural resources or ecosystems that require levels above its capacity for regeneration and assimilation, among other factors.

On the other hand, [6] mentions that both natural and social environments are parts of the same equation, consequently, inseparable. He goes on to mention that since men are part of nature and have knowledge and social values produced during the historical process, they also have the power to act permanently on its natural base of support, changing its properties and causing changes in dynamic social environment.

This author has the view that the relationship between man and nature is the essence of environmental issues and that it is not enough to drive a process of analysis and reflection leading to the understanding of this relationship in all its complexity. He points out that this is the key to the understanding of environmental issues in the world of culture, namely in the sphere of the whole of society. Hence, we may say the practices of social en- 
vironment will determine the nature of environmental problems. Furthermore, the concentration of population in large cities causes major environmental damage such as flooding, landslides and housing, among others [7]. According to [8], there is a need to reflect and to structure a Public Environmental Management, which is able to overcome environmental problems.

In this context, environmental management and public administration acquire great relevance in the search for solutions to these socio-environmental problems, taking into account the possibility of job creation and sustainable opportunities for citizens, public and private organizations [9]. Since environmental issues are public policy assets, public management of federal entities in Brazil must also take into account the environmental policy based on the 1988 Federal Constitution, which establishes the principle that "everyone has the right to an ecologically balanced environment. In addition, there are other principles established in the Constitution: a) sustainability, which establishes the duty of the government and the community to defend and preserve the natural environment for current and future generations; b) environmental responsibility, blaming the burden of impacts and recovery of environmental causative agent damages.

However, [10] points out that in everyday life, the process of appropriation and use of natural resources do not occur in a harmonic way. There are either potential or explicit conflicts between social actors, social classes and sectors of society in order to control his or her defense and protection, despite the constitutional principle that "everyone is entitled to an ecologically balanced environment”. Still, according to this author, the Government is primarily responsible for environmental protection in Brazil, and it is their duty to intervene in conflicting processes to ensure the quality of life. Thus, this author considers the environmental management as a mediator to conflict of interest, either potentially or explicitly.

Based on the Article 2, Paragraph I of the 6938 Federal Law from August 31, 1981 which provides for the National Environmental Policy, it is the responsibility of public administration in relation to the environment: governmental action in maintaining the ecological balance, considering the environment as a public asset to be necessarily guaranteed and protected with a view of collective use.

The public environmental management must combine operational policies and administrative practices that take into account the health and safety and environmental protection through the elimination or minimization of impacts and environmental damage resulting from the planning, implementation, operation, expansion, relocation or deactivation of developments or activities, including all phases of the lifecycle of the product [11]. In this sense, the public management of the municipalities has an important role, despite the decisions of a centralized environment to levels of state and federal government.

In Brazil, municipalities, especially those with low populations and different territorial realities, are extremely heterogeneous, whose main characteristic is the diversity of socio-economic situations, administrative structures and modes of governance.

As for this creation and autonomy, municipalities are recent. Until 1937, Brazil had only increased to 125 municipalities as compared to 2429 until 1988. The greatest increase occurred after the Constitution of 1988, stimulated by the criterion of apportionment of the Municipal Participation Fund (MPF). Between 1989 and 1997, 1307 municipalities were created, most of which with fewer than 20,000 inhabitants, concentrated in the South, Southeast and Northeast. In 2010, about 89\% of the 5565 Brazilian municipalities had up to 50,000 inhabitants [12]. There is high variation in the size of the area municipalities, ranging from $3 \mathrm{~km}$ (Santa Cruz de Minas-MG) to $1540 \mathrm{~km}^{2}$ (Altamira-PA). There is also variation in the available revenue as tax collection is concentrated at the Federal and State Governments [13].

According to [14], the greatest difficulties are found at the local government level, and especially in the counties of low population group. In this regard, [15] examines one of the big problems is regionalism oligarchy, controlling public expenditure, something that the 1988 Constitution did not change significantly. From [16]'s point of view, the municipalities were not immune to the remnants of a local political culture resistant to democratic accountability, centralized breeding practices in public administration, called by [17] "executivismo” or “prefeituralização”, although there’s advice policymakers.

The Federal Constitution of 1988 established the public policy management councils as channels of popular participation, share responsibility for municipal public administration. They have been described as political reinvention of cells capable of controlling the government, to make it susceptible to social demands and to promote participatory learning. However, the hegemony of state power, civic passivity and lack of resources to operate the nature of their actions. In most cases, boards become bureaucratic instruments to endorse the decisions of the executive and ensuring the transfer of resources. 
The solution to environmental problems and their minimization requires updated information and even managers trained to make decisions and adopt administrative complex technologies to help expand the capacity of public administration at all three levels of government. To this end, indicators of ecological zoning of the State of Minas Gerais have information that can contribute towards developing public policies and support government decisions, especially in the data collected about the city public environmental management.

\section{Natural Vulnerability and Social Potential of the Cities of Minas Gerais: Methodological Aspects}

\subsection{The Ecological Economic Zoning of Minas Gerais (ZEE-MG)}

The EEZ-MG is formed by the composition of two diagnoses, one of the natural vulnerability of regions and social potential of the other municipalities, both represented by cartographic means. We generated three integrated cards, two themes (Potential Environmental and Social Vulnerability), see Figure 1 and Figure 2, a charter of synthesis of subsidy to land management (ecological zoning of the State of Minas Gerais), with the respective indexes: Natural Vulnerability Index, Index of Potential Social and Ecological-Economic Index (EEI).

The charter of natural vulnerability addressed the relationship between men and the environment, and the natural vulnerability understood as "[...] the inability to resist a spatial unit and/or recover after suffering impacts from human activities considered normal” [18].

On the one hand, the methodology used to diagnose the biotic and abiotic, contained in the charter of natural vulnerability of the EEZ-MG, was based on a set of methods and techniques articulated to collect information and generate indicators for geology, geomorphology, pedology, mining, climatology, hydrology and hydrogeology, flora and fauna of the state and the municipalities of Minas Gerais.

The data were systematized and aggregated according to the factors that influence natural vulnerability used for the EEZ-MG, namely soil vulnerability, vulnerabilities of water resources, climatic conditions, the flora and

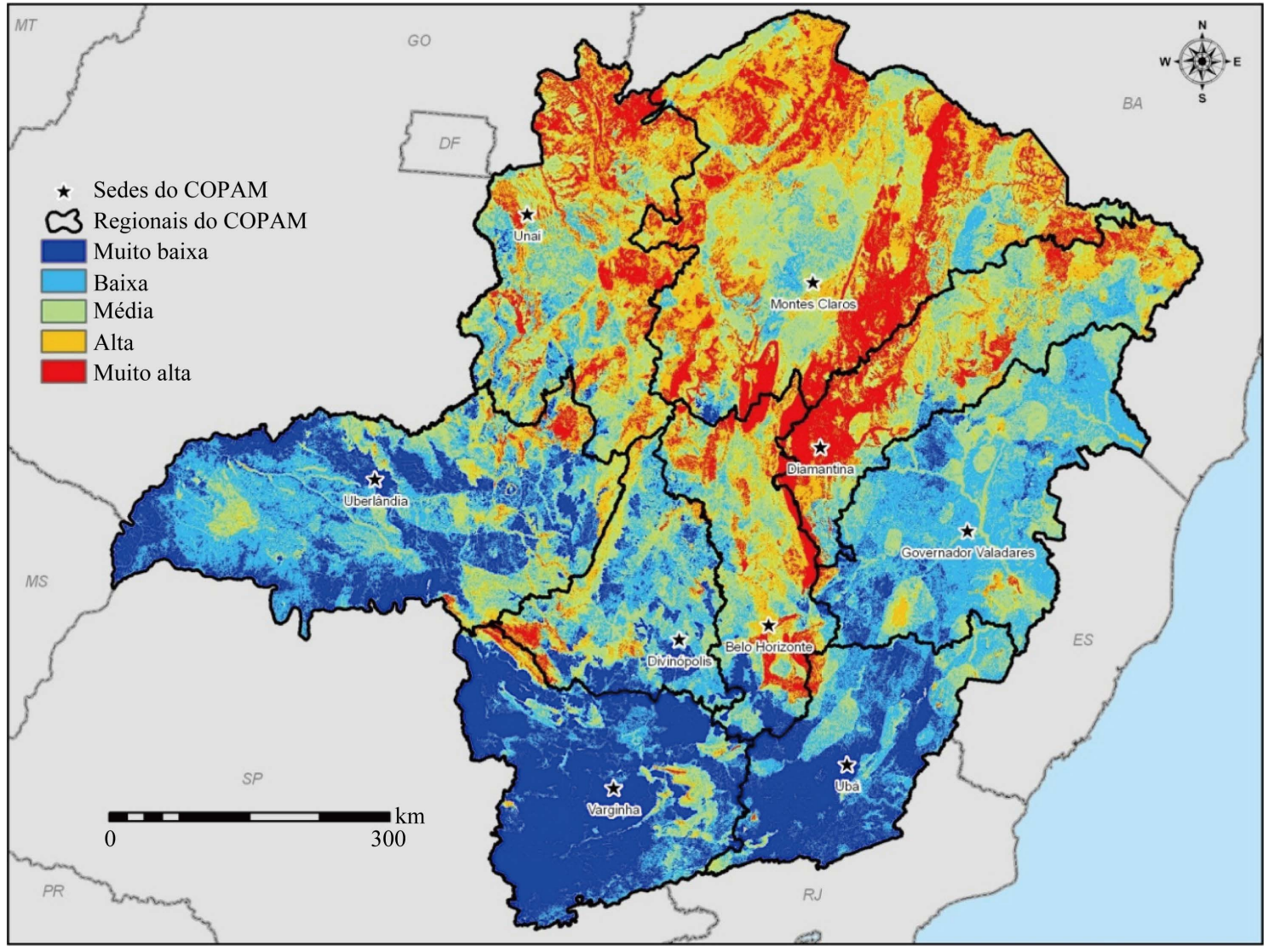

Figure 1. Charter of natural vulnerability of Minas Gerais, 2008. Source: [36]. 


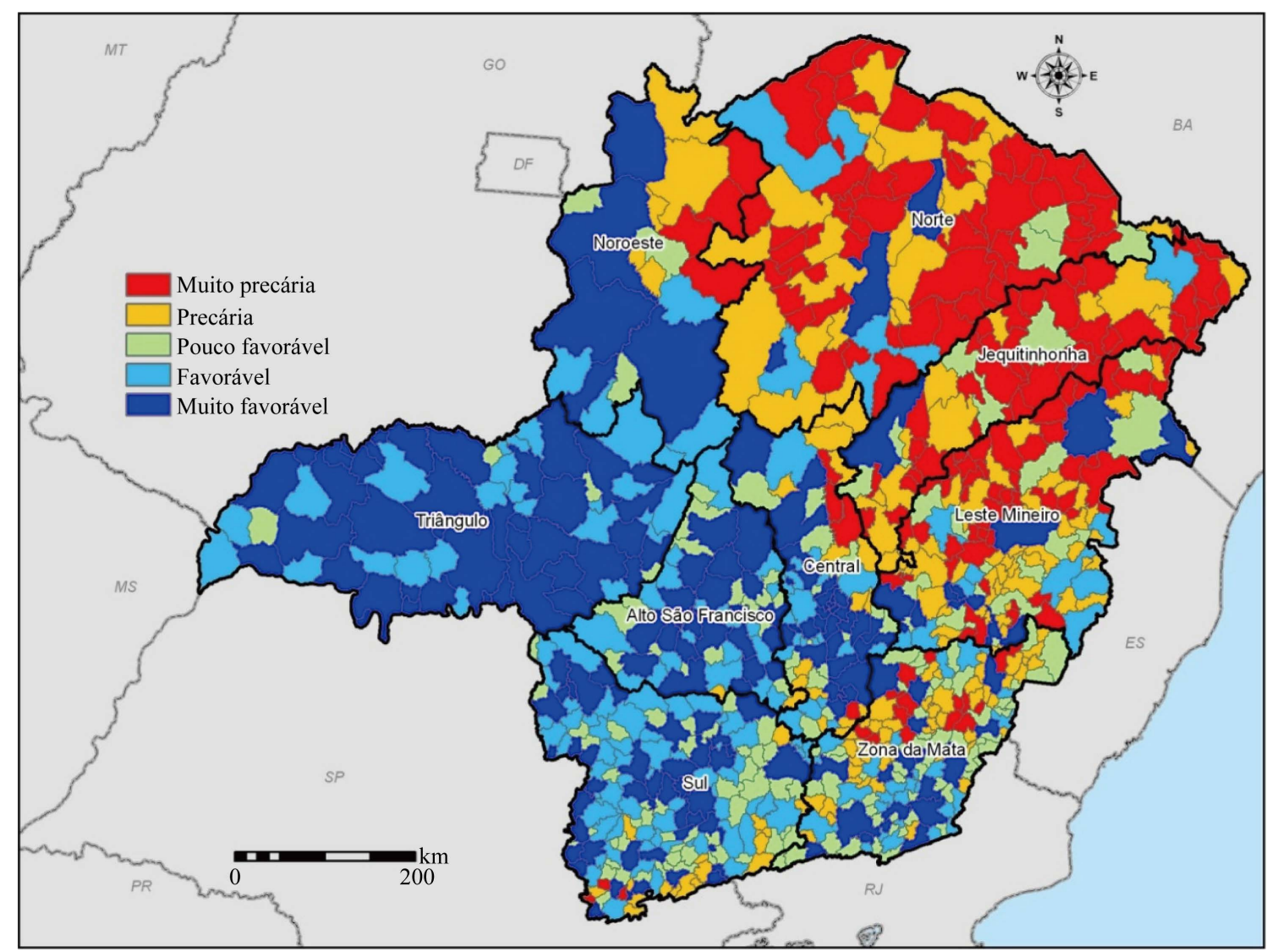

Figure 2. Social potential charter of the municipalities of Minas Gerais. Source: [37].

fauna integrity. The charter synthesis of natural vulnerability was constructed by superposition with the same weight of weighting for each risk factor. Thus, we defined five classes of vulnerability to human activities, as shown in Table 1. The results were organized into a database and represent the state of each cell mapping (pixel) of $270 \mathrm{~m} \times 270 \mathrm{~m}$, which can be detailed at the local or regional. On the other hand, the Charter of Social Potential of EEZ-MG represents a set of information capable of providing an integrated and synthetic component in the studied area, which is productive, natural, human and institutional. As stated by [19], the charter of social potential is in line with the methodological guidelines of the Ministry of Environment (MMA), which conceptualizes the EEZ as "[...] an instrument of political and technical planning, whose ultimate purpose is optimize the use of space and public policies" [20].

According to [22], the starting point of social potential of cities and regions of the state of Minas Gerais should be identified through the categorization of municipalities, which will allow the public manager to evaluate and direct the investment of resources each reality properly. To categorize the cities we took as reference to compare the data of the 853 municipalities in Minas Gerais in order to situate them within a continuum that ranges from a minimum value (one point) and a maximum (five points) used for each indicator, represented symbolically by the charters of the alphabet "A, B, C, D, E". Thus, each point and each charter corresponds to a specific category, representative of the social potential of each municipality [23] and their starting point for sustainable development.

The points corresponding to each class, according to Table 2 were assigned according to the result of applying the method of multivariate analysis by principal component, establishing five percentile ranges (quintile) for each indicator according to the variability of the data. The categorization of municipalities has as basic assumption the fact that municipalities start from different points of the manufacturing, natural, human and institutional conditions, and therefore should be treated differently, which means treated differently in the context of public management, equitable treatment of the reality of each municipality in its both specificity and demands. Thus, based on this categorization, the Government of Minas Gerais can make strategic decisions, set goals, resources, 
Table 1. Classes of natural vulnerability.

\begin{tabular}{cl}
$\begin{array}{c}\text { Classes of } \\
\text { Vulnerability }\end{array}$ & Characteristics of Natural Areas \\
\hline Very high & Present serious restrictions on the use of natural resources \\
High & Present significant restrictions on the use of natural resources \\
Average & Present moderate restrictions on the use of natural resources \\
Low & Present low restrictions on the use of natural resources \\
Very Low & They have very low significant restrictions on the use of natural resources \\
\hline
\end{tabular}

Source: [21].

Table 2. Categories of social potential.

\begin{tabular}{cl}
\hline Category/Score & Type of Social Potential \\
\hline $\mathbf{A}=\mathbf{5}$ & The starting point in very favorable conditions \\
$\mathbf{C}=\mathbf{4}$ & Starting point for favorable conditions \\
$\mathbf{D}=\mathbf{2}$ & Starting point in little favorable conditions \\
$\mathbf{E}=\mathbf{1}$ & Starting point in precarious conditions \\
\hline
\end{tabular}

Source: [25].

deadlines, and develop plans for specific cities or entire regions more accordingly to each situation. In addition, power will be designing specific scenarios as a strategy for public intervention and social [24].

The aggregation of all the information and indicators relating to aspects of production, natural, human and institutional conditions is synthesized in the Potential Social Index (IPS) of the EEZ-MG. Consequently, it justifies the categorization of municipalities and provides insight into the main land using trends, forms and modes of production and living conditions associated with them on the grounds of Agenda 21: "[...] that the development will be built under an optical integrator which sees the country in close connection with human capital.” [26].

The basis of the information used is disaggregated to the level of municipalities, represented in charts and available in a database composed solely of evidence and information obtained from official sources of institutions or agencies of recognized competence, either, federal, state or local. More importantly, such information, despite coming from different sources, must be considered and analyzed as a whole, as summarized in the Index of Potential Social (IPS), and not piecemeal or isolated, as the joints between them are able to demonstrate the configuration of a given reality, both local, regional and the actual state of Minas Gerais. Therefore, it is the articulation of information that forms the basis of formation of the IPS [27].

To ensure wide access to spatial data available in the EEZ and alphanumeric-MG, facilitating the dissemination of information required to manage the territory, an application was developed-SIGWEB. Thus, all information used referring to the 853 municipalities in Minas Gerais are available on the Internet website www.zee.mg.gov.br in the form of tables, graphs and maps.

Besides these considerations, the Social Capability in the EEZ-MG represents the actual condition, especially the "social capital", what Sen (2000) calls for substantive freedom, a prerequisite for sustainable development. Thus, we assumed that every municipality has determined that a Social Capability is a starting point for Sustainable Development. That is, every city has a set of natural, productive, human and institutional elements, which is the "Point of Departure for Social Potential" [28].

It is understandable, then for this author, as the social potential set of current conditions, measured by the size production, natural, human and institutional conditions, which determine the starting point of a municipality or a region to achieve sustainable development.

One indicator that is part of the institutional component of the social potential of the EEZ-MG is the Local Environmental Management, which expresses the managerial capacity of municipalities in terms of formal structure aimed to resolve or minimize environmental problems. This indicator consists of the following variables: a) Existence of a department or similar body to address the environmental issue, which is the degree of 
organization of the administrative structure of local governments in the environmental area, showing the commitment of the municipality with the treatment of environmental issues such as wildlife conservation and flora, maintenance and regulation of green areas and environmental protection, waste management, pollution control, among others; b) The existence of an environmental secretary, which indicates the degree of organization of the administrative structure of local governments, as well as their commitment towards the Municipal Environmental Management; c) Existence of the municipal council of the environment, which represents space for social participation and negotiation of demands, interests and conflicts in order to complement the traditional forms of indirect democratic representation; and d) Existence of municipal background environment, which is an accounting and aims department to fund projects and implement actions related to the control, supervision, protection and restoration of the environment of the municipality, consisting of specific budget allocations.

In turn, these results in the collection of fines established in environmental legislation, reimbursement of the cost of services provided by the Municipality to applicants for licenses provided for in laws, transfer of the Union, the State or other public entities and donations from other sources and resources; the participation in intermunicipal consortium in the environmental area [29]. It represents a form of local or regional political articulation including agreements between municipalities for the achievement of objectives of common interest, by means of works, activities and common services in the region covered by them. Its existence, to expand the service capacity of citizens to solve problems and without prejudice to their autonomy, increases the communication between the prefectures of state and federal governments, and creates instances of regional expression in the treatment of local problems; watershed committees represent the articulation of regional municipalities, formed by collective bodies composed by government representatives, local councils and water users, with the task of managing watersheds in a participative and decentralized way.

\subsection{The Social Mining Responsibility Index (IMRS)}

The Social Mining Responsibility Index (IMRS) is an initiative of the State of Minas Gerais to express the level of development of each mining town, considering seven dimensions such as education, health, public safety, environment and housing, culture, sport and leisure, employment, income and municipal finances.

About 40 indicators were used in this composition and arranged in seven different dimensions. In each of these dimensions relevant topics were selected to portray the situation, the role of public management and initiatives related to participation in decisions. The index ranges from 0 to 1 , values which represent respectively the worst and the best situation [30].

For this study we used a sub-index of dimension "environment and housing" where the indicators related to environmental protection are expressed, excluded for the purposes of this study the housing conditions of the population. Therefore, we analyzed the following indicators: percentage of population affected by diseases related to inadequate sanitation, percentage of population with access to water for general network, percentage of population with access to sewage treatment, percentage of population with access to treated waste; percentage of the municipal area with full protection; percentage of the municipal area of sustainable use, percentage of cover by native flora, percentage of vegetation cover through reforestation; per capita expenditure of the municipality with the environment budget.

\section{Capacity Management and Environmental Problems in the Cities of Minas Gerais}

Further down are the results of the charters of natural vulnerability (Figure 1), the social potential (Figure 2) EEZ-MG, and highlighted the charter of Environmental Local Management (Figure 3).

The state government of Minas Gerais, Brazil, adopted from 2002, a program of change in the management methods in public administration, known as "Management Shock", which involved designing an "institutional suitability for development" and an "integrative perspective of public policies" [31]. According to these authors, the government has prioritized 30 strategic projects, named structuring projects, which were included in a portfolio of projects contemplated by budgetary resources. The EEZ-MG is one of the structuring projects, number 17 [32]. Its premise is "[...] help plan and guide public policies and actions in the environment in the regions, through a macro state diagnostics," using criteria of economic, social, ecological and environmental elements [33].

The overall objective of the EEZ is "to contribute to the definition of strategic areas for the sustainable de- 


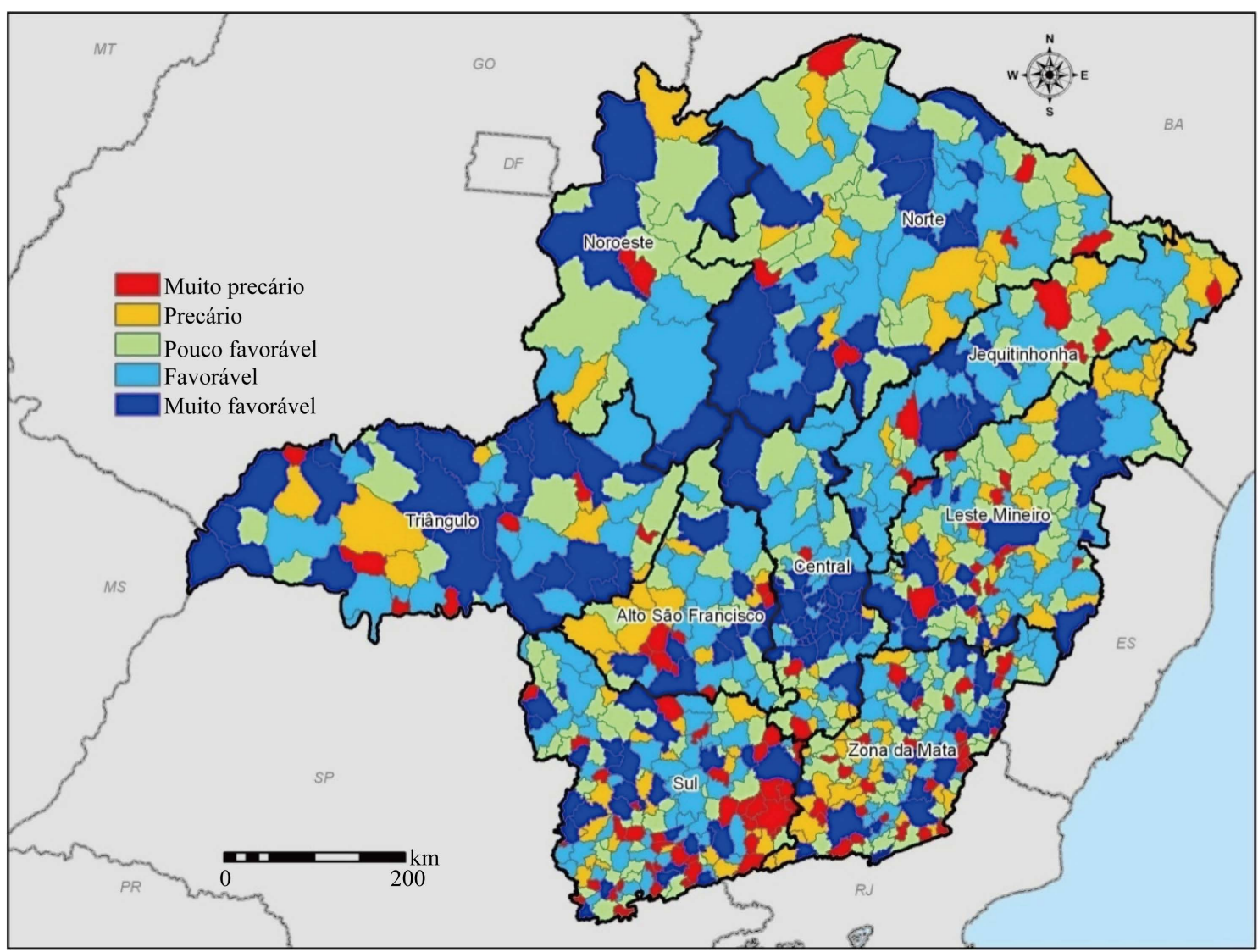

Figure 3. Charter of environmental management indicator of municipalities in the state of Minas Gerais, ZEE-MG, 2007. Source: [38].

velopment of Minas Gerais, targeting investment from government and civil society according to the regional peculiarities" [34].

Moreover, the EEZ seeks to reveal the potential of municipalities understood as economic facilities, social opportunities, political liberties, social interactions and protective security [35]. The EEZ-MG may also prove the following: That individuals have opportunities to use economic resources for consumption purposes, production, exchange and distribution arrangements that society provides individuals with in the areas of education, health, work, income amongst others, which influence the substantive freedom of the individual to live better, articulated and consistent information that can provide the transparency of the State in establishing criteria for commercial contracts and possibilities of social management of natural resources, institutional arrangements accessible to citizens in order to exercise their rights and dues; other provisions reveal the social organization of the state of Minas Gerais.

The charter of natural vulnerability of Minas Gerais is shown on Figure 1. The results indicate the natural vulnerability of the possibility of environmental problems due to human occupation and allow for recommendations for better resources use, control and protection.

The results show high vulnerability in the northern state (red color on the map), very low in the blue areas represent the southern, forest area and part of the mining triangle and high Paranaíba. This means that municipalities in northern Minas Gerais, Brazil, are situated in a natural environment unable to resist or recover itself by normal human action. Areas are very fragile to the actions of man where the most serious environmental problems can occur. The public management of the state government should pay special attention to the municipalities located within those areas. The blue areas of the map represent land more resistant to the actions of man in general, such as intensive agriculture. Above all, the public administration should take preventive actions, mitigation and recovery for these areas.

A charter of potential social shows the results of each municipality on Figure 2. One can see clearly inequali- 
ties between municipalities with very poor potential (red areas on the map) and municipalities with very favorable social potential (blue areas).

The municipalities located in the blue areas are the starting point favorable or very favorable, for instance, where there are strong economic activities, hospitals, universities, technology centers, industries, shopping centers and public institutions. The red areas on the map stand out as the most precarious in terms of potential social, i.e., the starting point of the municipalities located in such areas is very poor, better still, the poorest municipalities where the major economic, social, institutional and human problems take place. In these areas, some municipalities are observed under very favorable conditions (in blue), forming islands of true social potential. These municipalities are considered poles of development, as good indicators congregate human and institutional productive elements. Generally, the populations of neighboring municipalities require education services, health and trade, among others. The results show the characteristics and patterns of land use, demographic, economic and living conditions of the population.

Finally, the indicator card Environmental Management hall is shown on Figure 3. This indicator expresses the managerial capacity of municipalities in terms of formal structure aimed to resolve or minimize environmental problems.

The results show that municipalities in the red color on the map are those extremely poor to formal managerial capacity to solve environmental problems at their own risk. The municipalities located in the blue colors of the map represent those who have formal managerial capacity to go about environmental problems. There is a real mosaic of colors on the map, which means that, in addition to a municipality that has managerial capacity, there lies another municipality without the same formal capacity. Based on these findings, we can infer that the public administrations of the municipalities do not communicate among themselves nor share the knowledge of structure and formal organization dedicated to solving common environmental problems that affect them.

Based on reliable data, the Miner Social Responsibility Index (IMRS) has generated a sub-index that expresses some of the environmental problems, overcoming these problems by formal management capacity of municipalities in Minas Gerais.

The lowest values were found in groups of up to 20,000 and 50,000 inhabitants. The growth rates of sub-indices in these two groups also grew less. Data are presented in Table 3 in the form of percentage of population that have available some kind of service and basic environmental spending per capita with the sanitation activities. These activities suffered large increases in the years 2006 to 2009 due to its inclusion in the Growth Acceleration Plan (GAP). The urban and rural sanitation, involve four basic activities: water supply, sanitation, urban sanitation and solid waste management, drainage and urban storm water management program. The data analyzed include the sanitation and solid waste management, which concentrate more resources on the part of municipal governments.

Nearly twenty years after the Constitution promulgation, these guidelines were embodied in Law number $11.445,5^{\text {th }}$ January, 2007. Other entities of the Federation have a responsibility in this policy, since it is also common responsibility of the national, states, Federal District and municipalities to promote improved sanitation (Section IX of the art. 23 of the Federal Constitution), protect the environment and fight pollution no matter the circumstances (item VI of art. of 23 Federal Constitution).

Table 3. Index of environmental problems for groups of municipalities according to population size, Minas Gerais, Brazil, 2000-2010.

\begin{tabular}{|c|c|c|c|c|c|c|}
\hline \multirow{2}{*}{$\begin{array}{l}\text { Groups of Municipalities } \\
\text { (Number of People) }\end{array}$} & \multicolumn{5}{|c|}{ Municipal Environmental Problems_-IMRS (Arithmetic Mean) } & \multirow{2}{*}{$\begin{array}{l}\text { Geometric Annual } \\
\text { Growth Rate (\%) }\end{array}$} \\
\hline & 2000 & 2002 & 2004 & 2006 & 2008 & \\
\hline Up to 20,000 & 0.335 & 0.352 & 0.350 & 0.350 & 0.421 & 2.9 \\
\hline More than 20,000 to 50,000 & 0.350 & 0.361 & 0.365 & 0.368 & 0.459 & 3.4 \\
\hline More than 50,000 to 100,000 & 0.337 & 0.354 & 0.352 & 0.352 & 0.427 & 3.0 \\
\hline More than 100,000 to 300,000 & 0.377 & 0.383 & 0.397 & 0.407 & 0.508 & 3.8 \\
\hline More than 300,000 to 700,000 & 0.385 & 0.434 & 0.460 & 0.549 & 0.626 & 6.3 \\
\hline More than 700,000 & 0.425 & 0.517 & 0.529 & 0.635 & 0.649 & 5.4 \\
\hline State of Minas Gerais & 0.341 & 0.357 & 0.357 & 0.358 & 0.435 & 3.1 \\
\hline
\end{tabular}

Source: [39]. 
It was found that there has been evolution of environmental indicators in all segments of municipalities. We can also observe that even considering the growth rates, the low populous counties - up to 50,000 inhabitantshad indicators lower than those of high quota areas. It was concluded that the larger the population of the municipality, the greater per capita spending with better sanitation and quality indicators. This allows us to infer a positive correlation between expenditure power, population size and better quality of life.

Table 4 presents the data of the city, by segment and total, the state of Minas Gerais, to adopt practices of environmental sanitation. Despite strong government investment in the second half of the 2000s, there is still a very precarious situation of low-populous counties. In these municipalities there is still a significant portion of people in rural areas, impairing the wider range of actions and achieving efficiency in the use of public resources.

The smaller the population of the municipality, is lower the presence of sanitation. However, these small municipalities are waste composting plants, with low incidence of landfills and dumps. Consequently, under the State Law for disposal of solid waste, the "Mining-Free Dumps" program was created with targets to eradicate 80 percent of mining dumps in the municipalities.

\section{Final Thoughts}

The aim of this study was to analyze the capacity of public administration to solve environmental problems in the state of Minas Gerais, Brazil. We show that this action is somehow limited, but is in the process of consolidation through institutional and managerial tools. It was also shown that the weaknesses of public administration to solve environmental problems are located in the counties of low population groups. The lack of managerial capacity of these municipalities is related to the structure, the formal organization of municipalities, the centralization of environmental levels of state and federal government.

The worst case scenario for public management, both local and state or federal, in the face of environmental problems, is formed by municipalities located in areas of high natural vulnerability of potential social and a key indicator of very poor environmental management. To make matters worse, there are the low standard facilities of less densely-populated cities, where sanitation and waste disposal are precarious. On this front, the challenges of public management are immense and, therefore, must be addressed through specific policies for these areas. An initiative in this direction is targeted by public policies for the "Territories of Citizenship", characterized by poor conditions common to a group of municipalities. Such policies give priority to social inclusion, deliberative democracy and social management of the resources provided by the State.

The best case scenario for managing environmental problems facing the public is the one formed by munici-

Table 4. Proportion of municipalities according to population strata, which adopt an activity of collecting and treating waste and sewer sanitary, Minas Gerais, Brazil, 2000-2010.

\begin{tabular}{|c|c|c|c|c|c|c|c|c|c|c|c|c|}
\hline \multirow{4}{*}{ Indicator (Municipalities) } & \multicolumn{12}{|c|}{ Population Stratum (Number of Habitants) } \\
\hline & \multicolumn{2}{|c|}{ Up to 20,000} & \multicolumn{2}{|c|}{$\begin{array}{c}20,000 \text { to } \\
49,999\end{array}$} & \multicolumn{2}{|c|}{$\begin{array}{l}50,000 \text { to } \\
99,999\end{array}$} & \multicolumn{2}{|c|}{$\begin{array}{l}\text { Greater than } \\
100,000\end{array}$} & \multicolumn{2}{|c|}{ Belo Horizonte } & \multicolumn{2}{|c|}{$\begin{array}{c}\text { Minas } \\
\text { Gerais State }\end{array}$} \\
\hline & 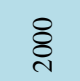 & $\stackrel{\circ}{\stackrel{2}{\sim}}$ & §ి & $\stackrel{\circ}{\circ}$ & §ి & 을 & $\underset{\sim}{\stackrel{2}{2}}$ & $\stackrel{\circ}{\circ}$ & 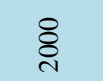 & 웅 & 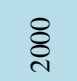 & $\stackrel{\circ}{\circ}$ \\
\hline & \multicolumn{12}{|c|}{ Proportion of municipalities in relation to the total, which adopt the practices (\%) } \\
\hline $\begin{array}{l}\text { Existence of general network of sewer } \\
\text { sanitary }\end{array}$ & 2.81 & 10.96 & 12.5 & 41.96 & 35.14 & 51.35 & 78.57 & 53.57 & 100.0 & 100.0 & 8.09 & 18.29 \\
\hline $\begin{array}{l}\text { Service system for collection and waste } \\
\text { treatment (at least } 70 \text { percent of the } \\
\text { resident population) }\end{array}$ & 2.22 & 15.70 & 1.79 & 13.29 & 0.0 & 32.43 & 14.29 & 39.29 & 100.00 & 100.0 & 2.52 & 16.79 \\
\hline $\begin{array}{l}\text { Existence of sewer sanitary treatment you } \\
\text { receive (where at least } 50 \text { percent of the } \\
\text { population is served) }\end{array}$ & 0.74 & 11.85 & 0.89 & 12.50 & 2.70 & 27.03 & 0.0 & 32.14 & 0.0 & 100.0 & 0.82 & 13.36 \\
\hline \multicolumn{13}{|l|}{ Existence of waste treatment system } \\
\hline Landfill sanitary & 0.0 & 1.63 & 1.79 & 9.82 & 0.0 & 29.73 & 0.0 & 39.29 & 100.0 & 100.0 & 0.12 & 5.28 \\
\hline Composting plant & 1.78 & 13.48 & 0.0 & 1.79 & 0.0 & 0.0 & 0.0 & 0.0 & 100.0 & 100.0 & 1.41 & 10.9 \\
\hline
\end{tabular}

Source: [40]. 
palities located in regions of low natural vulnerability of very favorable potential social, environmental management as of very favorable an indicator and the municipalities of medium to large population. Such scenario lends itself to manage and deal with environmental problems by using infrastructure resources, materials, equipment and qualified personnel, amongst others. However, environmental problems cannot be resolved by other factors such as local political, institutional and legal aspects.

Between these extreme realities, public management is a situation of municipalities that deserves careful treatment, but above all, preventive and strong investment in the structure and formal organizations focused on environmental management. In this scenario, it is necessary to strengthen the role of environmental management councils, qualify and train people to face environmental problems and invest in infrastructure and material resources for sustainable development.

Finally, one must consider that the state of Minas Gerais is a step forward compared to other states of the Federation, as regards the possibilities of overcoming environmental problems. There is quality information quality, which is well-organized through the EEZ-MG and the IMRS for all of its 853 municipalities. These macro diagnostics enhance significantly the capacity of public administration to identify and contribute to solving potential environmental problems.

\section{References}

[1] IMRS (2011) Belo Horizonte: Fundação João Pinheiro. www.fjp.mg.gov.br

[2] Carvalho, I. and Scotto, G. (1995) A Natureza, é Nossa? Democracia Viva, Ibase, Rio de Janeiro, 112, 28-29.

[3] CMMAD (Comissão Mundial sobre Meio Ambiente e Desenvolvimento) (1991) Nosso Futuro Comum. Editora Fundação Getúlio Vargas, Rio de Janeiro.

[4] Munhoz, T. (2005) Desenvolvimento Sustentável e Educação Ambiental. São Paulo. www.intelecto.net/cidadania/meio-5.html

[5] Medeiros, P.C. (2005) A Face Oculta da Privatização e os Desafios da Gestão Social das Águas no Estado do Paraná. Raega, Curitiba-PR, 1, 117-130.

[6] Quintas, J.S. (2006) Introdução à gestão ambiental pública. 2nd Edition, IBAMA, Brasília, 134 p.

[7] Cunha, M.A.V.C. (2000) Portal de Serviços Públicos e de Informação ao Cidadão: Estudo de casos no Brasil. Tese (Doutorado em Administração), Universidade Federal de São Paulo—FEA/USP, São Paulo.

[8] Quintas, J.S. (2006) Introdução à gestão ambiental pública. 2nd Edition, IBAMA, Brasília, 134 p.

[9] Silva, R.C.F. (2003) Gestão Urbana e Desenvolvimento Sustentável. Instituto de Ensino Superior da Amazônia, Notas prévias de aula, Manaus.

[10] Quintas, J.S. (2006) Introdução à gestão ambiental pública. 2nd Edition, IBAMA, Brasília, 134 p.

[11] Juchem, P.A. (1995) Introdução à Gestão, Auditoria e Balanço Ambiental para Empresas. Notas prévias de aulas, Faculdade de Administração e Economia, Curitiba.

[12] IBGE (2011) Sinopse do censo demográfico 2010. Instituto Brasileiro de Geografia e Estatística, Rio de Janeiro.

[13] Rezende, J.B., Leite, E.T. and Araujo, V.M. (2008) Análise das transferências de recursos financeiros intergovernamentais e das transferências monetárias diretas às famílias: $\mathrm{O}$ caso dos municípios mineiros de baixo contingente populacional. In: Encontro de Administração Pública e Governança, Anais do Encontro de Administração Pública e Governança, ANPAD, Salvador.

[14] Neves, E.M.S.C. (2006) A Política Ambiental e os Municípios Brasileiros. Tese (Doutorado em Ciências Sociais), Instituto de Ciências Humanas e Sociais, Universidade Federal Rural do Rio de Janeiro, Rio de Janeiro.

[15] Arretche, M.T.S. (2004) Federalismo e Políticas Sociais no Brasil: Problemas de coordenação e autonomia. São Paulo em Perspectiva, 18, 17-26.

[16] Abrucio, F.L. (2005) Os Avanços e os Dilemas do Modelo Pós-Burocrático: A reforma da administração pública à luz da experiência internacional recente. In: Bresser Pereira, L.C. and Spink, P.K., Eds., Reforma do Estado e Administração Pública Gerencial, 6th Edition, FGV, Rio de Janeiro, 173-200.

[17] Oliveira, R.O. (2004) Desenvolvimento e participação: O caso dos Conselhos Municipais de Desenvolvimento Rural do Estado de São Paulo. Campinas, 126 p.

[18] Carvalho, J.C., Carneiro, S., Cavalcante, H.C., Rolla, S.R., Mendes, A.N.G., Scolforo, J.R., Oliveira, A.D. and Carvalho, L.M.T. (2008) Apresentação do Zoneamento Ecológico-Econômico do Estado de Minas Gerais. In: Scolforo, J.R., Oliveira, A.D. and Carvalho, L.M.T., Eds., Zoneamento ecológico-econômico do Estado de Minas Gerais: zoneamento e cenários exploratórios, Editora UFLA, Lavras, 1-6, 8. 
[19] Pereira, J.R. (2008) Carta de Potencialidade Social. In: Scolforo, J.R., Oliveira, A.D. and Carvalho, L.M.T., Eds., Zoneamento Ecológico-Econômico do Estado de Minas Gerais: Componente socioeconômico, UFLA, Lavras, 167195.

[20] Brasil Ministério do Meio Ambiente, dos Recursos Hídricos e da Amazônia Legal (MMA) and Secretaria de Assuntos Estratégicos da Presidência (SAE/PR) (1997) Detalhamento da Metodologia para Execução do Zoneamento Ecológico-Econômico pelos Estados da Amazônia Legal. MMA, SAE/PR, Laboratório de Gestão do Território da Universidade Federal do Rio de Janeiro, Brasília, 12.

[21] Scolforo, J.R., Oliveira, A.D., Carvalho, L.M.T., Marques, J.J.G., Louzada, J.N., Mello, C.R., Pereira, J.R., Rezende, J.B. and Vale, L.C.C. (2008) Zoneamento ecológico-econômico de Minas Gerais. In: Scolforo, J.R., Oliveira, A.D. and Carvalho, L.M.T., Eds., Zoneamento ecológico-econômico do Estado de Minas Gerais: Zoneamento e cenários exploratórios, UFLA, Lavras, 7-20.

[22] Pereira, J.R. (2008) Construção dos Indicadores de Potencialidade Social. In: Scolforo, J.R., Oliveira, A.D. and Carvalho, L.M.T., Eds., Zoneamento Ecológico-Econômico do Estado de Minas Gerais: componente socioeconômico, UFLA, Lavras, 7-34.

[23] Pereira, J.R. (2008) Construção dos Indicadores de Potencialidade Social. In: Scolforo, J.R., Oliveira, A.D. and Carvalho, L.M.T., Eds., Zoneamento Ecológico-Econômico do Estado de Minas Gerais: componente socioeconômico, UFLA, Lavras, 7-34.

[24] Pereira, J.R. (2008) Construção dos Indicadores de Potencialidade Social. In: Scolforo, J.R., Oliveira, A.D. and Carvalho, L.M.T., Eds., Zoneamento Ecológico-Econômico do Estado de Minas Gerais: componente socioeconômico, UFLA, Lavras, 7-34.

[25] Pereira, J.R. (2008) Construção dos Indicadores de Potencialidade Social. In: Scolforo, J.R., Oliveira, A.D. and Carvalho, L.M.T., Eds., Zoneamento Ecológico-Econômico do Estado de Minas Gerais: componente socioeconômico, UFLA, Lavras, 7-34.

[26] Bezerra, M.C.L., Facchina, M.M. and Ribas, O.T. (2002) Agenda 21 Brasileira: Resultado da consulta nacional. Ministério do Meio Ambiente, Programa das Nações Unidas para o Desenvolvimento, Brasília, 26.

[27] Pereira, J.R. (2008) Carta de Potencialidade Social. In: Scolforo, J.R., Oliveira, A.D. and Carvalho, L.M.T., Eds., Zoneamento Ecológico-Econômico do Estado de Minas Gerais: Componente socioeconômico, UFLA, Lavras, 167-195.

[28] Pereira, J.R. (2008) Carta de Potencialidade Social. In: Scolforo, J.R., Oliveira, A.D. and Carvalho, L.M.T., Eds., Zoneamento Ecológico-Econômico do Estado de Minas Gerais: Componente socioeconômico, UFLA, Lavras, 167195.

[29] Brasil (2005) Lei n ${ }^{\circ}$ 11.107, de 06 de abril de 2005. Dispões sobre normas gerais de contratação de consórcios públicos e da outras providências. Senado Federal, Brasília, DF.

[30] FJP (2011) Índice Mineiro de Responsabilidade Social—IMRS. Fundação João Pinheiro, Belo Horizonte. www.fjp.mg.gov.br

[31] Vilhena, R., Martins, H.F., Marini, C. and Guimarães, T.B. (2006) O Choque de Gestão em Minas Gerais: Políticas da gestão pública para o desenvolvimento. UFMG, Belo Horizonte, 363 p.

[32] Minas Gerais (2005) Secretaria de Estado do Meio Ambiente e Desenvolvimento Sustentável (SEMAD). Gestão Ambiental no Século XXI (PE 17): Termo de referência SAT/DIZON nº 001/05. SEMAD/MG, Belo Horizonte.

[33] Carvalho, J.C., Carneiro, S., Cavalcante, H.C., Rolla, S.R., Mendes, A.N.G., Scolforo, J.R., Oliveira, A.D. and Carvalho, L.M.T. (2008) Apresentação do Zoneamento Ecológico-Econômico do Estado de Minas Gerais. In: Scolforo, J.R., Oliveira, A.D. and Carvalho, L.M.T., Eds., Zoneamento ecológico-econômico do Estado de Minas Gerais: Zoneamento e cenários exploratórios, Editora UFLA, Lavras, 1-6.

[34] Carvalho, J.C., Carneiro, S., Cavalcante, H.C., Rolla, S.R., Mendes, A.N.G., Scolforo, J.R., Oliveira, A.D. and Carvalho, L.M.T. (2008) Apresentação do Zoneamento Ecológico-Econômico do Estado de Minas Gerais. In: Scolforo, J.R., Oliveira, A.D. and Carvalho, L.M.T., Eds., Zoneamento ecológico-econômico do Estado de Minas Gerais: Zoneamento e cenários exploratórios, Editora UFLA, Lavras, 1-6.

[35] Sen, A.K. (2000) Desenvolvimento como Liberdade. Companhia das Letras, São Paulo, 409 p.

[36] Scolforo, J.R., Oliveira, A.D., Carvalho, L.M.T., Marques, J.J.G., Louzada, J.N., Mello, C.R., Pereira, J.R., Rezende, J.B. and Vale, L.C.C. (2008) Zoneamento ecológico-econômico de Minas Gerais. In: Scolforo, J.R., Oliveira, A.D. and Carvalho, L.M.T., Eds., Zoneamento ecológico-econômico do Estado de Minas Gerais: Zoneamento e cenários exploratórios, UFLA, Lavras, 245.

[37] Pereira, J.R. (2008) Carta de Potencialidade Social. In: Scolforo, J.R., Oliveira, A.D. and Carvalho, L.M.T., Eds., Zoneamento Ecológico-Econômico do Estado de Minas Gerais: componente socioeconômico, UFLA, Lavras, 167-195.

[38] Salazar, G.T., Oliveira, E.R., Silva, S.S., Arruda, M.A., Rocha, P.A.M. and Rodrigues, L.A. (2008) Componente Institucional. In: Scolforo, J.R., Oliveira, A.D. and Carvalho, L.M.T., Eds., Zoneamento ecológico-econômico do Estado de 
Minas Gerais: Componente socioeconômico. UFLA, Lavras, 101-140, 129.

[39] FJP (2011) Índice Mineiro de Responsabilidade Social_-IMRS. Fundação João Pinheiro, Belo Horizonte. www.fjp.mg.gov.br

[40] FJP (2011) Índice Mineiro de Responsabilidade Social—IMRS. Fundação João Pinheiro, Belo Horizonte. www.fjp.mg.gov.br 
Scientific Research Publishing (SCIRP) is one of the largest Open Access journal publishers. It is currently publishing more than 200 open access, online, peer-reviewed journals covering a wide range of academic disciplines. SCIRP serves the worldwide academic communities and contributes to the progress and application of science with its publication.

Other selected journals from SCIRP are listed as below. Submit your manuscript to us via either submit@scirp.org or Online Submission Portal.
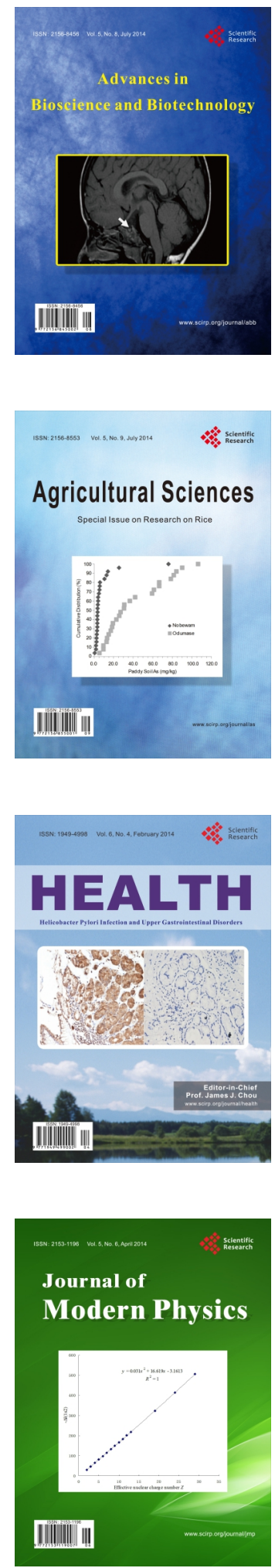
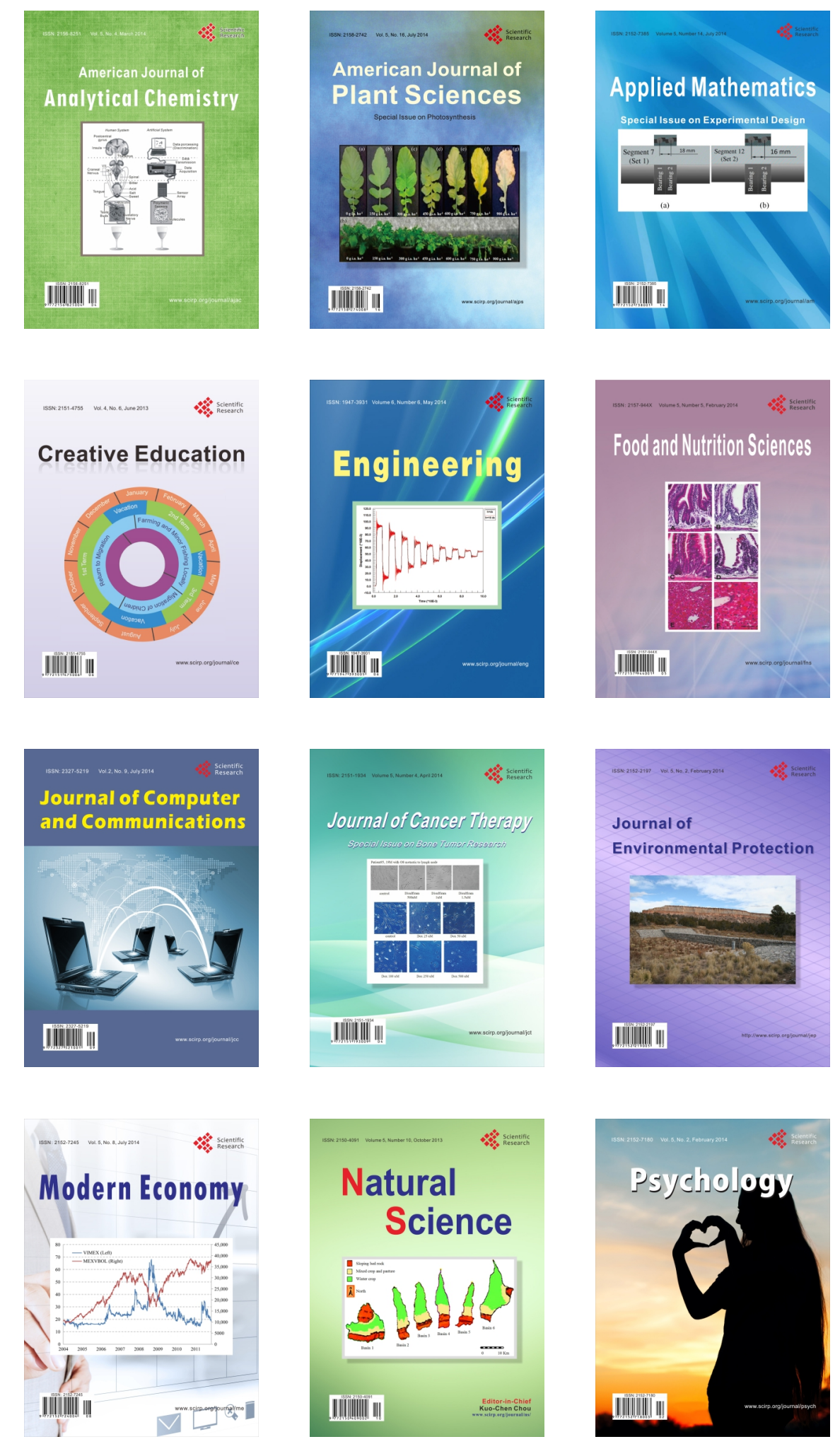